DOI: $10.17148 /$ IARJSET.2021.8930

\title{
STUDY ON PHYSICO CHEMICAL PARAMETERS OF SOIL SAMPLE
}

\author{
Pramod Manohar Ghare', Amruta Prakash Kumbhar ${ }^{2}$ \\ 1,2 PG- Environmental Science, Sies College, Mumbai University, Mumbai.
}

\begin{abstract}
Soil is the most diverse, nutrient rich loose surface material which covers most of our land. Soil contains both the organic and inorganic matter. The presence of soil is necessary to prevent direct leaching of the inorganic pollutants in the groundwater. Color, texture, structure, porosity, density, consistency, temperature, air are the physical properties of soil. Suitability of soil for agriculture is determined by the physical properties. There are different properties for different soil. Soil is the source of the water and provide mechanical stability to the plants. There are various types of soil in the environment for example - loamy soil, sandy soil, chalk, peat, silt, clay soil. Soil analysis refers to a set of various chemical processes which help us determine the available plant nutrients which are either in micronutrient or macronutrient form. In this study, various physiochemical parameters (texture, color, pH, salinity level, electrical conductivity, density, water holding capacity) were monitored. Along with chemical, microbial analysis was also carried out in order to understand the microbial diversity in the soil. After carrying our this analysis, we understood that the properties of soil keeps on changing depending on various anthropological activities carried out nearby. The range in which values lie keeps on fluctuating, sometimes under range, sometimes totally beyond it. Through such studies, we endeavor to highlight the potential for hazardous impact that nature might face due to excessive anthropological activity.
\end{abstract}

Keywords : Soil parameters, anthropological activity, physiochemical parameters

What is soil?

\section{INTRODUCTION: -}

The earthy materials in which the plant grow to known as soil, which has been derived from the Latin word "solum". Soil is defined as an independent body in the nature with a unique morphology from the surface down to the parent material as expressed as the sample profile. Soil is the thin layer which is covering the earth surface and in the formed as weathering of rocks. Soil is mainly made of organic materials, mineral and living organism. Almost all the plant get nutrients from the soil and they are main sources of food for all living organism. Soil have the ability to remove impurities, destroy disease which is cause harmful effects and degrades contaminants. Soil mainly absorbs the oxygen and methane that release carbon dioxide and nitrous oxide. Soil giving physical support to all the other factors such as air, water, temperature moderation, nutrients and other one is protection from the harmful toxins. The conservation dead organic matter into nutrients for plants, takes place in soil. Most living things depends on soil for their existence. Soil is most valuable resources that should be conserved properly because it's damaged easily and washed or blown away. If we understand that soil is important source for life, we will avoid destroying one of the most important essential building block of our environment and our food security. Soil is made of various components; the composition of soil and proportion of these component greatly influence on the soil physical properties which is include the soil structure and porosity. These properties influence air and water movements in soil and thus the ability of soil function. Soil play important role in to quantify the physical, chemical and biological parameters that impacts on the agricultural productivity and sustainability. The main part of soil organic matter is a complex assemblage of small organic molecules, collectivity called as the humic substances.

As the soil develops the over time, layers (horizons) from a soil profile. Soil covers the earth by two main layers such as topsoil and subsoil. Most soil exhibits into the three main horizons:-

Horizon- The nutrients, organic matter and biological activity were found to be highest in the horizon rich layer of topsoil. B horizon- it is Clay-rich subsoil. This horizon is often less fertile than the topsoil but its holds more moisture content.

C horizon- underlying weathered rock.

Some soil also have an $\mathrm{O}$ horizon mainly consisting of plant which as the accumulated on the surface of soil. Weathering is process may be physical, biological and chemical process.

Soil is a critical natural resources that provides for our environment by many ways. Soil is a diverse medium with its own diverse ecosystem. Soil is food for some creature and home to many organism. Soil helps to clean our water, recycling the nutrients, provide the place for plant growing. Soil impact the weather and provides to materials for anthropogenic activities. 


\section{International Advanced Research Journal in Science, Engineering and Technology}

\section{Vol. 8, Issue 9, September 2021}

\section{DOI: 10.17148/IARJSET.2021.8930}

Soil degradation refers to the process by which soil ecological diversity is destroyed. Soil degradation refers to the process by which soil ecological diversity is destroyed. Soil degradation is most serious environmental problem. Soil degradation among global issue which is impact on world food security and quality of the environment. Soil are fundamental natural resources, are the basic for all the terrestrial life. Mechanism that initiate the soil degradation includes chemical, physical, and biological processes. Importance things of physical processes are a decline the structure of soil and leads to crusting, desertification, erosion, compaction, anaerobium, environmental pollution and unsustainable use of natural resources. Chemical processes includes salinization, leaching, acidification decrease in the cation retention capacity and fertility depletion of soil. Biological process include reduction in total and biomass carbon and decline in land diversity. Thus soil degradation is a biophysical process driven by political and socioeconomic causes.

Soil may look still and lifeless, but this impression couldn't be further the truth, it is constantly changing and developing through time. Soil is always responds to change in the environmental factors, along with the influences of man and land use. Some changes in the soil will be short duration and reversible, other will be permanent features of soil developments. The pollution of soil are common todays and it happens due to presence of anthropogenic activities. The reason why the soil is a become contaminants due to the presence of manmade activities and other resources. Natural waste like used. Some natural hazards may leads to soil degradation includes that land topography and climatic factors such as steep slopes, blowing of high velocity wind, frequent floods and tornadoes, one of the main reason is rain of high intensity and drought condition in dry regions. The prominent degradation feature is erosion by water. Managing and cultivating soil is a more sustainable way to reduce the environmental pressure all over the world.

Soil degradation is classified into 4 parts:

Water erosion

Wind erosion

Chemical deterioration

Physical deterioration

Soil is naturally composed of various type minerals, organic constituents and the broken rocks which have been altered by the different environmental reactions. Soil is natural sink for various type pollutants and different types of contaminants. Pollutants or contaminants find their way into the soil, interacts with the soil particle and changes occurs in chemical and physical properties of the soil. Pollution mostly occurs from the agricultural practice and industrials activity. However, natural resources of pollution or contamination cannot be ruled out.

The soil is the most important constituents to fulfillment of all the basic needs to human beings. A healthy soil has chemical, physical, and biological properties that leads the health of animal, plant and humans while maintain environmental quality. Physiochemical study of soil is very significant. The physicochemical study of base on the different parameters like electrical conductivity, texture, $\mathrm{pH}$, moisture content, texture, temperature, available nitrogen, organic matter, potassium and phosphorous. This knowledge will help us to understand the status of soil and helps to the people who are interested in agricultural field.

Many times the nutrients present soil may exceeds the desire limits due to natural or manmade activities or may lacks the certain nutrient, in such cases measure need to be taken to maintain to the soil health. Soil pollution is caused by the addition of minerals to soil by peoples, from the use of agriculture chemical such as insecticide, herbicide, weedicide, fungicide from the dust fall and use of contaminated water and fertilizers. It is also caused due to agricultural waste, industrial waste, urban waste, radioactive waste and biological pathogens. The industrial effluents increase the toxicity levels of soil. Due to sewage soil pollution is very high.

\section{STUDY AREA}

The study are includes the coastal line area from the Gujarat region. The soil sample were collected from each area any season. The name and location of these area in that given below:

1. Dandi, Gujarat, India

The all seven samples are collected from the Gujarat region. The average temperature of this region in summer is $49^{\circ} \mathrm{C}$. Climate of Gujarat is fluctuating due to coastal line area. In the winter the temperature is vary from $12^{\circ} \mathrm{C}$ to $29{ }^{\circ} \mathrm{C}$. The latitude and longitude of study area is given below.

\begin{tabular}{|l|l|l|l|}
\hline Sample & latitude & longitude & Temperature \\
\hline Sample 1 & $20^{\circ} 51.484^{\prime}$ & $72^{\circ} 48.735^{\prime}$ & $25^{\circ} \mathrm{C}$ \\
\hline Sample 2 & $20^{\circ} 51.480^{\prime}$ & $72^{\circ} 48.701^{\prime}$ & $25^{\circ} \mathrm{C}$ \\
\hline Sample 3 & $20^{\circ} 51.450^{\prime}$ & $72^{\circ} 48.696^{\prime}$ & $21^{\circ} \mathrm{C}$ \\
\hline
\end{tabular}


International Advanced Research Journal in Science, Engineering and Technology

Vol. 8, Issue 9, September 2021

DOI: $10.17148 /$ IARJSET.2021.8930

\begin{tabular}{|l|l|l|l|}
\hline Sample 4 & $20^{\circ} 51.433^{\prime}$ & $72^{\circ} 48.710^{\prime}$ & $22^{\circ} \mathrm{C}$ \\
\hline Sample 5 & $20^{\circ} 51.401^{\prime}$ & $72^{\circ} 48.736^{\prime}$ & $21^{\circ} \mathrm{C}$ \\
\hline Sample 6 & $20^{\circ} 51.439^{\prime}$ & $72^{\circ} 48.738^{\prime}$ & $20^{\circ} \mathrm{C}$ \\
\hline Sample 7 & $20^{\circ} 51.512^{\prime}$ & $72^{\circ} 48.707^{\prime}$ & $20^{\circ} \mathrm{C}$ \\
\hline
\end{tabular}

\section{Study Map}
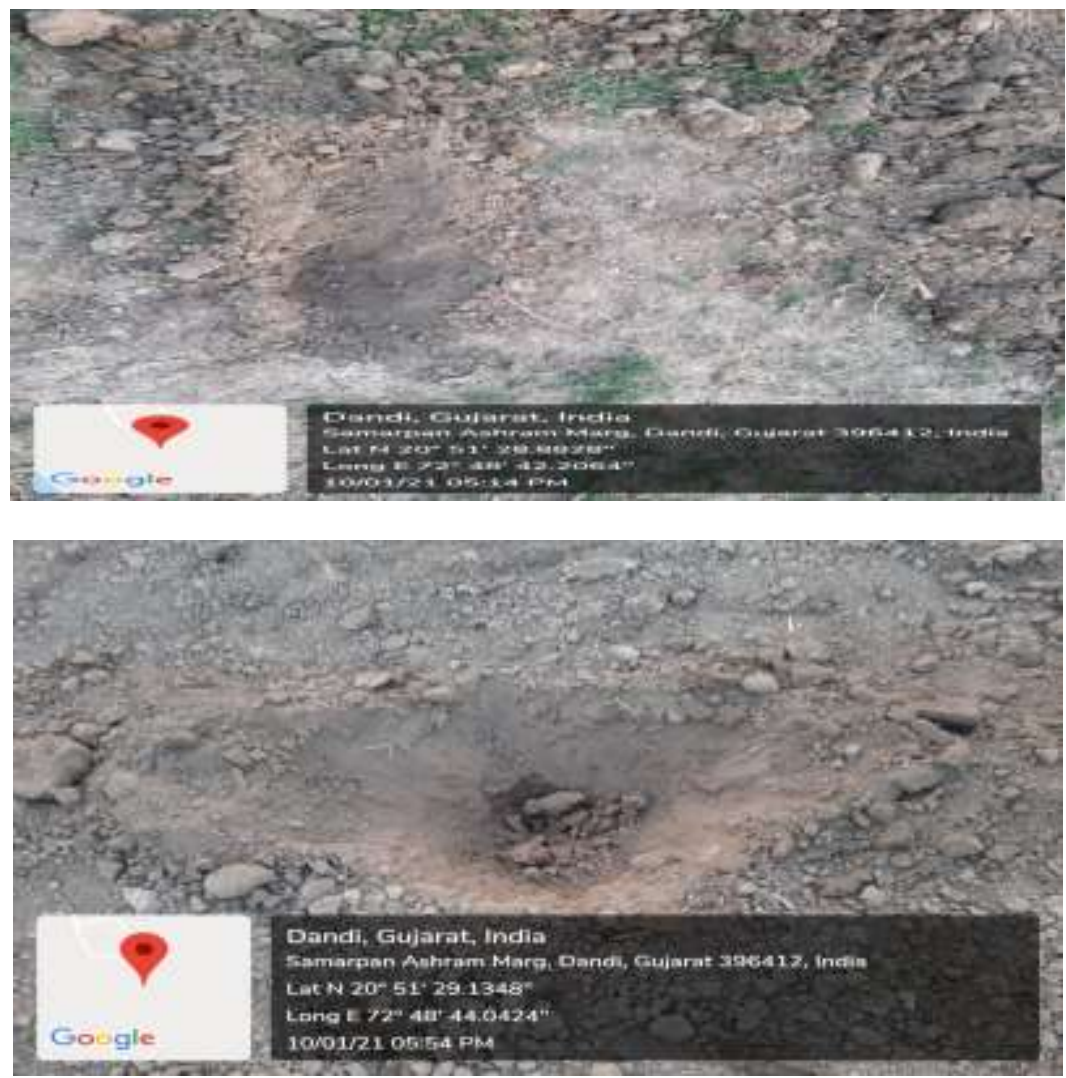

\section{PHYSICOCHEMICAL AND MICROBIOLOGICAL PARAMETERS}

Physicochemical analysis is a valuable practice that determines the exact amount of nutrients that are in the soil, such as phosphorus, potassium, organic content and $\mathrm{pH}$. It presents the information that is essential for the improvement of soil quality. It can also facilitate fertilization management, reveling the $\mathrm{pH}$ of soil level. Soil can be categorized on the basis of different physical and chemical properties. Whereas microbiological analysis indicates that species diversity and the health or condition of soil. The soil parameters given below:

pH:-

Soil $\mathrm{pH}$ is an indication of the acidity and alkalinity of soil and is measured in $\mathrm{pH}$ units. The negative logarithm of hydrogen ion were is basically referred to as soil $\mathrm{pH}$. The amount of hydrogen ions in the soil increases the $\mathrm{pH}$ of soil decreases thus becomes more acidic in nature. From the $\mathrm{pH}$ below 7 to 0 the soil is increasingly acidic. From the 7 to 14 soil will be alkaline in nature. Soil $\mathrm{pH}$ determined the soil properties easily. The accurate method to analysis of $\mathrm{pH}$ soil by $\mathrm{pH}$ meter.

\section{Conductivity}

Soil electrical conductivity (EC) is a nothing but the amount of salt in soil (salinity of soil). An imp indicator of soil health is conductivity. It has the potential to cause damage to the crop yields also the availability to nutrients to plant crop sustainability and soil microorganism. Excess salts hinder plant growth by affecting the soil-water balance. Soil containing excess salt occur naturally in arid and semiarid climates. Salt level can be result of irrigation, cropping and management of lands. EC represents the concentration of the nitrates, sulfates and ammonium chloride. For certain non- 


\title{
International Advanced Research Journal in Science, Engineering and Technology
}

\author{
Vol. 8, Issue 9, September 2021
}

\section{DOI: 10.17148/IARJSET.2021.8930}

saline soils, demining EC can be convenient and economical way to estimate the amount of nitrogen (N) available for the growth of plant. Conductivity is measured by conductivity meter.

\section{Water holding capacity}

Soil given oil water holding capacity is the amount of water that soil can be hold and then amount of pore spaces in the soil, where water and air can be found. Sandy soil have lower water holding capacity, while the slit and clay soil tend to have higher water holding capacity. The water holding capacity of the soil is determined by the amount of water held in soil sample vs. the dry weight of the sample by using the gravimetric analysis.

\section{Available phosphorous}

Phosphorous is a very essential elements classified as a micro-nutrients because of the relatively large amount of phosphorous required by plants. In soil phosphorous exists in many different forms and the solubility of phosphorous is very low. The phosphate used in fertilizers and manure is little bit soluble and available in nature. The phosphorous fertilizers and manure of phosphate come contacts with soil, various reaction start occurring that result in less soluble and less available of phosphate. Plants can take up only soluble inorganic and simple form of phosphate from soil and since most phosphorous in organic form, only a small fraction of inorganic phosphorus is present for plant. Phosphorous is most frequently determined by the Olsen method.

\section{Moisture content}

Water contained in the soil is called as the soil moisture. Soil water is major component of the soil in reaction to plant growth. The moisture content in soil is determined by amount of water present in the soil sample. Soil water dissolves salts and make it diluted which also makes sure that salinity stress is not caused and adequate supply of nutrient is there. Various method are available methods are available for determination of moisture content in soil but commonly used one is Oven Drying Method.

\section{Available potassium}

Potassium is very essential nutrients for plant growing. It is considered as the one of the most important micronutrients. In potassium deficient soil, plant growth gets altered, and the productivity of yield is decreases. The movement of soil potassium are depends upon the texture of soil. As the content of potassium increases moments get increase in the most of the soil. In sandy soil potassium is actually mobile and can leach out of the root zone. More amount of potassium affected to soil temperature and the oxygen level present in soil. Normally potassium content majored by the using photometer.

\section{Organic matter}

When most of organic content in the soil gets degraded $\mathrm{CO}_{2}$ is released and this $\mathrm{CO}_{2}$ is replaced some oxygen in soil pores.. Humus is portion of organic matter that remains after most decomposition has taken place. The organic matter decomposes in the soil, CO2 is released and replace some of the oxygen in soil pores. The amount of organic matter in the soil, management practices, soil temperature and drainage. Two common methods for analysis of soil organic matter are the walkey-black acid digestion and the weight loss on agitation method.

\section{Sodium}

Soil provide sodium into the plants. There is an accumulation of sodium from fertilizers, pesticides, herbicides and run off from shallow salt-laden waters and the breakdown of minerals which release salt. Sodium is not plant nutrients but it plays imp role in health of the soil. The high content of sodium can cause the salinity and sodicity problem such as the soil convert into the poor structure. The excess amount of sodium can decrease the soil permeability, its ability to readily conduct water and air, it can also decreases the soil's ability to cluster into easily crumbled masses of particle etc. sodium also determined in same ways by using the flame photometer.

\section{Available nitrogen}

Plant require more percent of nitrogen than any other types of macro and micro nutrients but only small amount of soil is available for plants; $98 \%$ of nitrogen in soil as organic form. Most of time the organic form of nitrogen cannot taken by plant directly. In contrast plants can readily take up minerals forms of nitrogen and including the different forms of nitrogen such as nitrate and ammonia. The amount of mineral nitrogen in soil amount for only $2 \%$ of the nitrogen present in soil. Soil micro-organism convert form of the nitrogen to minerals form of nitrogen when they decompose organic matter and fresh plant residues. This process is known as "mineralization".

\section{Chloride content}

Chloride is very essential micronutrients and all crops require chloride in small quantities. Most of the soil are $\mathrm{Cl}$ is highly soluble and is found predominantly dissolved in soil water. Chloride is found in soil as form of chloride anion. Being an anion it is fully mobile excepts where held by soil anion exchange site (Kaolinite clays, Iron and Aluminum Oxides). In some areas there rainfall is relatively high and internal soil drainage is also good, it may be leached from the soil profile. Chloride deficiency can occur when muriate of potash fertilizer is not applied on a daily basis.

Hypothesis:-

The following project is undertaken to study the different types of physicochemical and chemical parameters of soil. To check the quality of soil of Gujarat region 


\title{
International Advanced Research Journal in Science, Engineering and Technology
}

\author{
Vol. 8, Issue 9, September 2021
}

DOI: $10.17148 /$ IARJSET.2021.8930

\author{
Aim \\ physicochemical and chemical parameters of soil samples collected from different region. \\ Objective \\ 1. To estimate the available nutrients levels in soil. \\ 2. To provide recommendation if the soil contains more or less amount of nutrients \\ 3. To check different parameters \\ 4. To check agricultural activities of soil.
}

The main aim of the study is to check the status of soil of Gujarat region by studying various parameters of

\section{REVIEW OF LITERATURE}

The review literature is shortly describe the research paper and the articles referred during this project.

J.L Walworth (2011) in his publication on "soil sampling and analysis "summarized that Soil analyses can provide information that is important for maximizing nutrients use efficiency and agricultural productivity. A historical record of soil properties provided by long- term soil testing is useful for determining the effectiveness of fertilizers management's strategies in maintaining soil fertility and sustainable agricultural productivity. Soil testing is also a useful tools for identifying the cause of nutrients related plant growth problems ${ }^{[18]}$.

Swanti. A. Jain, et al.,(2014) in their research paper "Physico-chemical characterization of farmland soil in some villages of Lunawada Taluka. Dist.: Mahisagar (Gujarat) India”. Stated that the soil sample found to be fit for crop productivity. [19]

Wagh G. S., et al., (2013) in their research article "Physicochemical analysis of soil from Eastern Part of Pune City" concluded that the physicochemical analysis of the sample from Hadaspar, Manjari and Phursungi village towards SE of Pune city have influences of the uncontrolled solid waste disposal practice as well as industrial effluents. Most of the farmers are using the chemical fertilizers to much dose of such fertilizers in few soil has rendered high values of $\mathrm{P}$ and $\mathrm{K}$. in Pune city due to industrialization and other anthropogenic activity the soil from its eastern part has been polluted. [20]

The objective of the research paper "important of soil quality and soil agriculture indicators" (2014) are to review the currents efforts to define soil quality and to discuss factors and processes influencing soil quality, to identify, soil and crop management practices that affect processes influencing soil quality, and to demonstrate a method for evaluating soil quality and has given certain measure to maintain the soil quality. ${ }^{\text {21] }}$

Dr. Syed Ummul Khair Asema, et, al., (2015) from their research on soil analysis of Aurangabad city concluded that the physiochemical parameters of soil sample showed dissimilar value at different places. This can be due to the irregular distribution of different parameters in soil. Such types of monitoring of soil sample is beneficial to know the concentration of various parameters in soil samples. ${ }^{[22]}$

Sonikajha and Suneetha (2015) in their research paper Nutrients analysis of soil samples from various places stated that the analysis of nutrients is done in order to measure the nutrients is done in order to measure the nutrient application. The area for the study includes horticulture spot, lakeside agriculture area and mountain area. [23]

Dr. Christine Watson, et al; stated that soil analysis provides information which can be used to improve soil fertility through management, soil analysis is important in organic farming for nutrients management planning (e.g. rotational plans, making best use of manures, fertilizer application), to prevent long term nutritional and health problems (crop and livestock), prevention of pollution and for degradation for use of restricted inputs. Also they have mentioned about how to collect representative sample for various tests ${ }^{[24]}$

Jay Gholap, et al., (2012) aims at analysis of soil data mining techniques. It focuses on classification of soil using various algorithm available. From their research they concluded that In spite the fact that the least median squares regression is known to produce better results than the classical linear regression technique, from the given set of attributes, the most accurately predicted attribute was "P" (Phosphorous content of the soil) and which was determined using the linear regression technique in lesser time as compared to median squares regression. ${ }^{[25]}$

Ioan Suciu, et al., (2008) determined the concentration of five soil heavy metal $(\mathrm{Pb}, \mathrm{Co}, \mathrm{Cr}, \mathrm{Cu}$, and $\mathrm{Hg}$ ) from forty sampling sites in central Transylvania, Romania. The results indicated that some of these heavy metals exceeding at the alert level in the sensitive area (agricultural area). They concluded that the result of the study can lead to an image of the historical pollution, determining the concentration of several elements, according to the depths in the soil. [26]

Jacqueline Gibson, et al., (2013) demonstrated a study to show the effect of soil condition such as soil type and component on plant health in an urban environment. The result indicated that organic soil had higher plant health in an urban environment. The result indicated that organic soil had higher plant health but lower overall micronutrients than sandy and mixed soil types. ${ }^{[33]}$

Miss Yogita Kulkarni, et al., (2014) carried out Primary Nutrients Determination in the Soil Using UV Spectroscopy. Their objective of research was to analyze soil properties for accurately mapping various primary nutrients in the soil. Paper give review of sensor technology for determination of primary nutrients in the soil. Also results of UV spectroscopy 


\section{DOI: 10.17148/IARJSET.2021.8930}

for primary nutrients determination are discussed in the paper. It can be observed from the experiments that UV spectrophotometer can sense the various Primary nutrients in the soil. ${ }^{2]}$

Kirti Mohan Sharma, et al., (2017) performed the Physiochemical analysis of soil of Ladpura Tehsil of Kota District and they concluded that the majority of soil samples do not require additional or external source of nutrients and they are nutrient sufficient. They stated that this study will helpful for prediction of soil for various parameters such as salinity, alkalinity and acidity for particular area. With the help of study we found that it farmers grow crops on rotation basis it will prevent quality of soil and it will be much beneficial for soil health. ${ }^{[1]}$

Sarah Kizza et al., (2010) carried out Analysis of Persistence soil nutrients status in abandoned cattle kraals in semi acid area greatly enhance the nutrients status of these naturally nutrients deficient sandy soils. The organic wastes also result in marked improvements in the physical and moisture conditions of sandy soils. ${ }^{[3]}$

B. V. RamaKrishna, Dr. B. S atyanarayana (2016) carried out an experiment of applying data mining technique to study the agriculture soil to generate advisory reports which facilitate decision support to crop rotation, fertilizers requirements and harvesting procedures. The main aim is to reduce unnecessary fertilizers usage during cultivation of lands and to increase soil vitality. The experiments conducted in this paper concluded that Integration of data mining techniques with Agriculture sever turns it into an automated cultivation advisor and reduces laborious manual statistic analysis. ${ }^{[4]}$

Zeeshan Akraml, et al., (2014) studied the soil fertility and salinity Status of Muzaffargarh District, Punjab Pakistan the soil analysis data showed that $94 \%$ of the sample analyzed in district Muzaffargarh were not saline and that $74 \%$ were not sodic. For the purpose, a total of 3325 soil samples, collected from all tehsil of Muzaffargarh district (from tehsil Muzaffargarh, Jatoi, Kot Addu and Ali Pur), were tested in the Soil and Water Testing Laboratory, Cane Development Cell, Fatima Sugar Mills, Muzaffargarh, Pakistan from 2012 to 2014. [5]

Abubaker Haroun Mohamed Adam, et al., (2015) carried out Analysis of Soil NPK, pH, and Electrical Conductivity At Adham Area- Renk, upper Nile state, the objective of this study were to investigate soil type, potentially and reaction in relation to the scattered remaining vegetation species, and to quantify soil suitability for growing field crops. The result of statistical analysis depicted variability in NPK, $\mathrm{pH}$ and EC between the different locations and soil depths. Furthermore, the result showed an association between some studied soil attributes and the spatial distribution of the vegetation species. ${ }^{[6]}$

An article published in international journal of applied science and Biotechnology on Assessment of physio-chemical parameters of soil of muthannan kulam wetland, Coimbatore, Tamilnadu, India by K Manimegalai and S Sukanya (2014) indicated that the soil quality due to anthropogenic activities. The concentration of nitrogen, phosphorous and potassium is high due to the anthropogenic activities like domestic sewage, uncontrolled construction works, converting the ponds into agricultural areas, accumulation of heavy metals and hydrocarbons etc., in and around Muthannan kulam. ${ }^{[8]}$

A study was carried out by Teruo Yamanoto (1963) on soil moisture constant and physical properties of selected soil in Hawaii. He stated that most surface soils in Hawaii are fine textured and composed of aggregate of clay and colloidal particles. Soils studied on the island of Hawaii have the highest plastic limits, the wet area soils of Kauai and Oahu have intermediate values, and the dry area soils on the three islands have lower values of plastic limits. ${ }^{[9]}$

Katy Buthchee, et al., (2012) carried out a research on the impact of soil parameters ( $\mathrm{pH}$ ) on the Grain Sorghum Production. The results from this study varied from location to location and year to year, however a trend was detected that confirms that soil acidity reduced grain sorghum yield. This study demonstrated that the environment played a significant role in the degree of soil acidity stresses observed in grain sorghum production. ${ }^{[10]}$

\section{Collection of sample}

\section{MATERIALS AND METHOD}

The soil sample were collected randomly, with sterile equipment. The soil surface was dig up to $15 \mathrm{~cm}$ depth, the soil was mixed thoroughly and it was packed in a zip-locked plastic bag and it was taken to the laboratory for further analysis. Storage of sample

The sample was collected and brought in laboratory. For analysis part some part stored in freeze for microbial analysis and other part soil stored in hot air oven for drying purpose

\section{Analysis of Soil}

The soil samples were tested for different parameters like $\mathrm{pH}$, Electrical conductivity, water holding capacity, texture of soil, available potassium, available nitrogen, sodium, chloride, organic matter and enumeration of bacteria according to the standard procedure given in Maiti 2014.

\section{Analysis of soil}

pH

The $\mathrm{pH}$ of the soil was determined with help of $\mathrm{pH}$ meter as described in Maiti (2014) Handbook of methods in Environmental studies.

Principle 


\title{
International Advanced Research Journal in Science, Engineering and Technology
}

\author{
Vol. 8, Issue 9, September 2021
}

DOI: 10.17148/IARJSET.2021.8930

The soil pH is a nothing but negative logarithm of the active hydrogen ion $\left(\mathrm{H}^{+}\right)$conc. In the soil solution. It is the measure of soil acidity, neutrality or sodisity. $\mathrm{pH}$ is imp parameters, determining soil health because $\mathrm{Ph}$ influences the solubility of the nutrients and its availability to plant . It also affect microbial population in soils. Most nutrient elements are available range of 5.5 to 6.5

In various chemical estimations, $\mathrm{pH}$ regulation is critical. Specific colors as observed in the presence of various $\mathrm{pH}$ indicators and the color changes due to pH change are shown in Annexure-11.

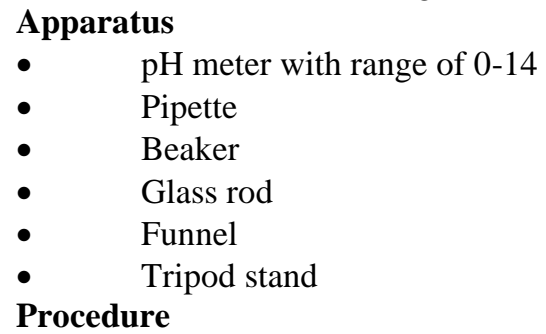

$10 \mathrm{~g}$ of oven dried, sieved samples were taken in a $100 \mathrm{ml}$ beaker and then add $50 \mathrm{ml}$ distilled water was added in it. The sample stirred for about $30 \mathrm{~min}$ and then filtered. The electrode of $\mathrm{pH}$ meter then dipped the solution and the $\mathrm{pH}$ was recorded.

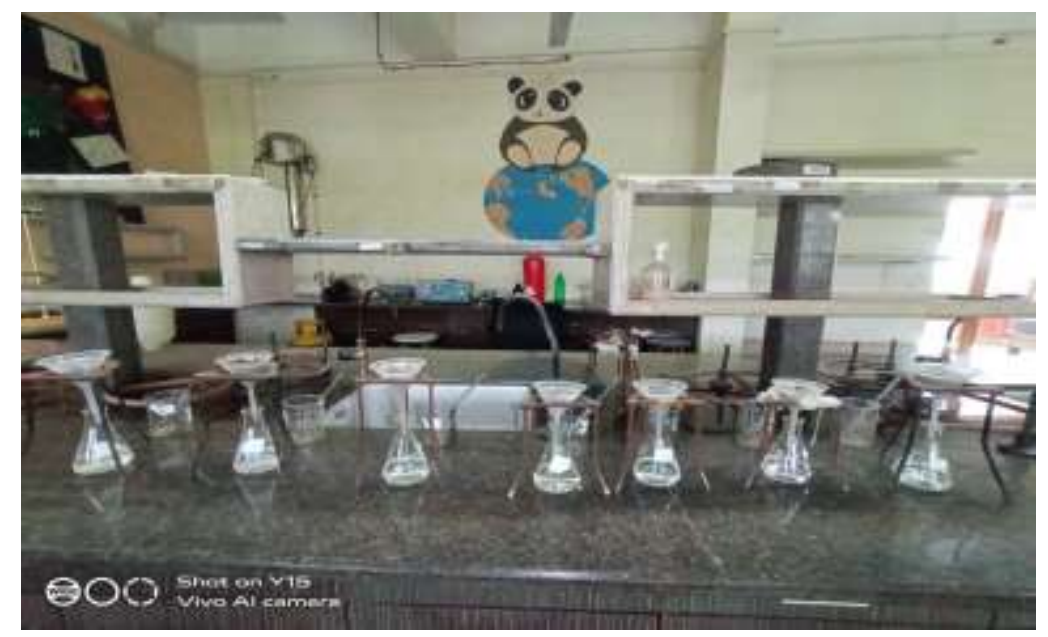

\section{Principle}

\section{ELECTRICAL CONDUCTIVITY}

EC of a solution can be defined as the measure of ionic transport in a solution between the anode and cathode. The means, the EC is normally considered to be a measurement of the dissolved salts in a solution. Like a metallic conductor, it's obey Ohm's law.

EC depends on the number of ions in the solution, it is important to know the soil/ water ratio used. The EC is normally considered to be a measurement of the EC in the soil solution extract from a saturated soil paste, as it has been found that the ratio of the soil solution in saturated soil paste is approximately two-three times higher than at field capacity.

As the determination of EC of soil solution from a saturated soil paste is cumbersome and demands 400-500 g soil sample for the determination a less complex method is normally used. Generally ratio is 1:2 soil/ water suspension is used.

$$
\begin{array}{ll}
\text { Apparatus } \\
\text { - } & \text { EC meter } \\
\text { - } & \text { Beakers }(25 \mathrm{ml}) \\
\text { - } & \text { Filter paper }
\end{array}
$$

\section{Procedure}

$20 \mathrm{~g}$ of oven dried, sieved samples were taken in a $100 \mathrm{ml}$ beakers and then $50 \mathrm{ml}$ of distilled water was added in it. The sample was stirred for about $30 \mathrm{~min}$ and then filtered using filter paper. The electrode of conductivity meter was dipped in the solution to get the reading. 
DOI: $10.17148 / I A R J S E T .2021 .8930$

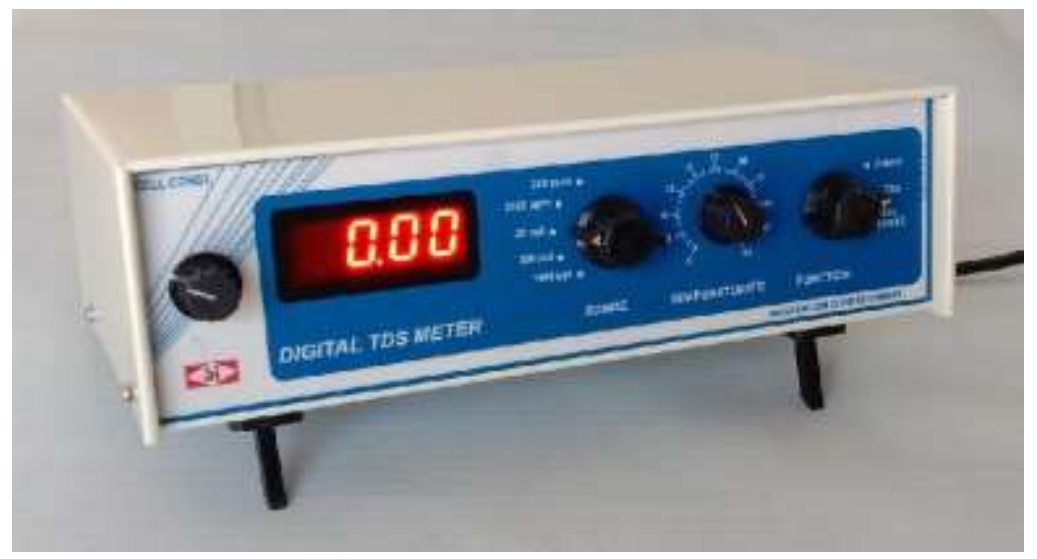

\section{Principle}

\section{WATER HOLDING CAPACITY}

Veihmeyer and Hendrickson (1931) defined the field capacity or the water holding capacity as the amount of water held in the soil after the excess gravitational water has drained away and after the rate of downward movements of water has materially ceased. Stage of field after 48 to 72 hours of saturation. It is the upper limits of plant available soil moisture. Water holding capacity of soil is an important parameters for plant growth. The maximum water holding capacity of soil is the amount of water taken up by the unit weight of the dry soil when immersed into water under standard condition.

$$
\begin{array}{cl}
\text { Apparatus } \\
\text { - } & \text { Crucible } \\
\text { - } & \text { Oven } \\
\text { - } & \text { Balance } \\
\text { - } & \text { Soil } \\
\text { - } & \text { Petri plate }
\end{array}
$$

\section{Procedure}

An empty crucible was weighted and the reading was recorded as W1. Then the oven dried, sieved sample was put into the crucible. The crucible was filled up to the brim. The crucible containing soil was kept on petridish containing water. The crucible was filled up to end. The crucible containing the soil was kept on petridish that containing water. The crucible was observed till the surface soils of crucible start appearing wet. As soon as was found that the water has reached to the surface, the crucible was removed from the petridish and weighed again and that was considered as W2. The crucible was kept in oven at $104^{\circ} \mathrm{C}$ for 24 hours. After 24 hours the crucible was removed from the oven and it was weighed and it was taken as W3. With the help of formula the water holding capacity of the sample were calculated.

\section{Formula}

Percentage of moisture in soil $=(\mathrm{W} 2-\mathrm{W} 3) /(\mathrm{W} 3-\mathrm{W} 1) * 100$

\section{Principle}

\section{ORGANIC CARBON / ORGANIC MATTER}

Organic matter estimation in the soil can be done by different methods. Loss of weight on ignition can be used as a direct measure of the organic matter contained in the soil. It can also be expressed as the content of organic carbon in the soil. It is generally assumed that on an average organic matter contains about 58\% organic carbon. Organic matter/ organic carbon can also estimate by volumetric and colorimetric methods. However, the use of potassium dichromate $\left(\mathrm{K}_{2} \mathrm{Cr}_{2} \mathrm{O}_{7}\right)$ Involved in these estimation in considered as a limitation because of its hazardous nature. Soil organic matter content can be used as an index of $\mathrm{N}$ in soil organic matter content can be used as an index of $\mathrm{N}$ availability (Potential of a soil to supply $\mathrm{N}$ to plants) as we know that because content of $\mathrm{N}$ in organic matter relatively same to be constant.
Apparatus
- $\quad$ Sieve
- Beaker
- Oven
- Muffle furnace
- Crucible 


\section{International Advanced Research Journal in Science, Engineering and Technology}

Vol. 8, Issue 9, September 2021

DOI: $10.17148 /$ IARJSET.2021.8930

\section{Procedure}

Weight 5.0 to $10.0 \mathrm{~g}$ (to the nearest $0.01 \mathrm{~g}$ ) sieved $(2 \mathrm{~mm})$ soil into an ashing vessel. Place the ashing vessel from the drying oven set at $105^{\circ} \mathrm{C}$ and dry for 18 hours. After the removing the ash ash vessel drying oven we need to place in a dry atmosphere. When it completely cooled, weigh to the nearest $0.01 \mathrm{~g}$. place the ashing vessel with soil into a muffle furnace for 24 hours. Remove the ashing vessel from the muffle furnace, cool in dry atmosphere and weight.

\section{Calculation}

Percent of organic matter $=(\mathrm{W} 1-\mathrm{W} 2) / \mathrm{W} 1 * 100$

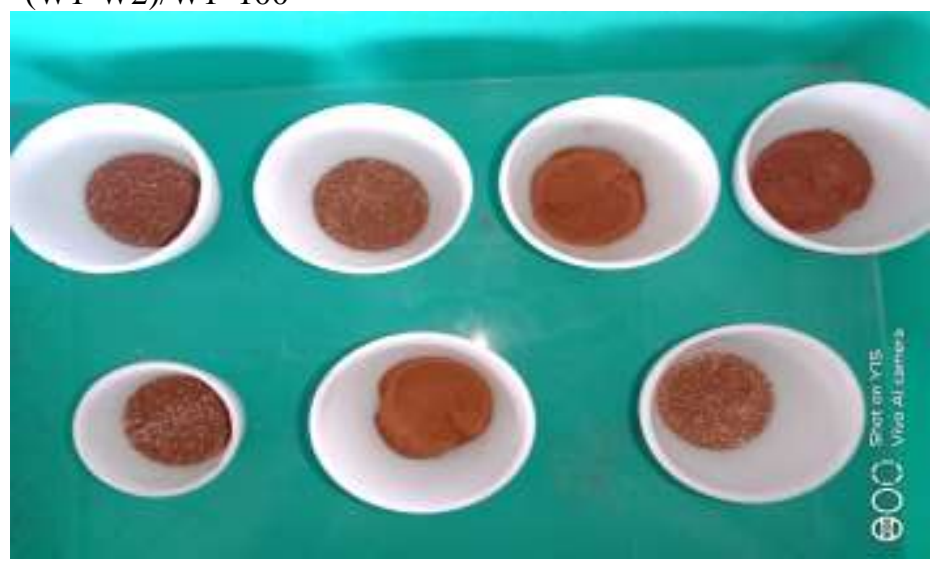

\section{Principle}

\section{CHLORIDE CONTENT}

Chloride ions get precipitated with the $\mathrm{AgNO}_{3}$ to form insoluble white precipitate of $\mathrm{AgCl}$. When all chloride ions are removed, the excess of $\mathrm{AgNO}_{3}$ reacts with potassium chromate forming silver chromate, which is red in color. The end point, therefore, is indicated by the change in color from bright yellow (due to $\mathrm{K}_{2} \mathrm{CrO}_{4}$ indicator) to brick red. The chemical reaction involved is as follows;
Apparatus
- $\quad$ Burette with stand
- Conical flask
- Glass rod
- Spatula
- Silver nitrate
- Potassium chromate

$\mathrm{AgNO}_{3}+\mathrm{Cl}^{-} \rightarrow \mathrm{gCl}^{-}$(White precipate) $+\mathrm{NO}_{3}{ }^{-}$

$2 \mathrm{AgNO}_{3}+\mathrm{K}_{2} \mathrm{CrO}_{4} \rightarrow \mathrm{g}_{2} \mathrm{CrO}_{4}$ (brick red precipitate) $+2 \mathrm{KNO}_{3}$

\section{Procedure}

$10 \mathrm{gm}$ of oven dried, sieved soil sample was dissolved in $100 \mathrm{ml}$ of distilled water. It was stirred properly for few minutes and then it was filtered. The filtered solution was transferred into $250 \mathrm{ml}$ conical flask. The filtered was acidify using $0.02 \mathrm{~N} \mathrm{H}_{2} \mathrm{SO}_{4}$ solution just to bring the $\mathrm{pH}$ between 6 and 7, by checking it with pH paper. Two drops of saturated potassium chromate indicator was added into it. The content was titrated with standard $\mathrm{AgNO}_{3}$ (silver nitrate) solution. The end point obtained was a persistent brick-red color started appearing. Simultaneously a blank was run without the soil sample.

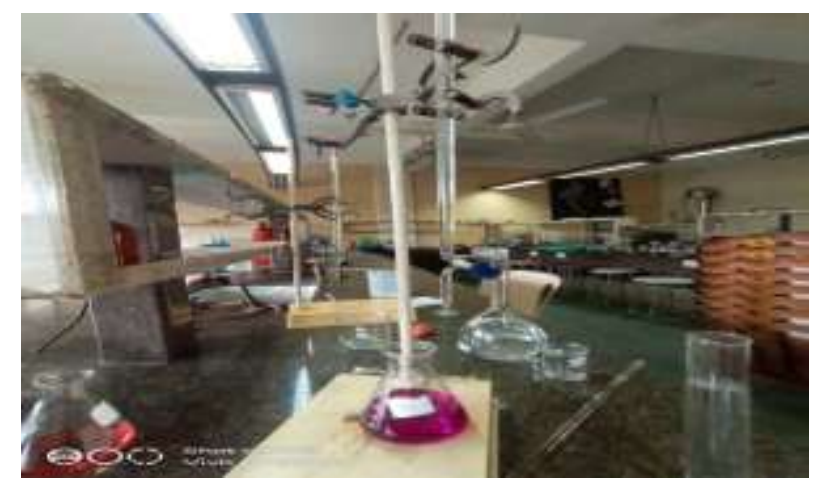


DOI: $10.17148 /$ IARJSET.2021.8930

\section{Principle}

\section{AVAILABLE NITROGEN}

The principle of this experiment is based upon the oxidation of organic compound using concentrated sulfuric acid. As the organic material gets oxidized, carbon gets converted to $\mathrm{CO} 2$ and hydrogen to $\mathrm{H}_{2} \mathrm{O}$. The nitrogen will get converted to ammonium ions which dissolve in oxidizing solution and can be converted to ammonia gas.

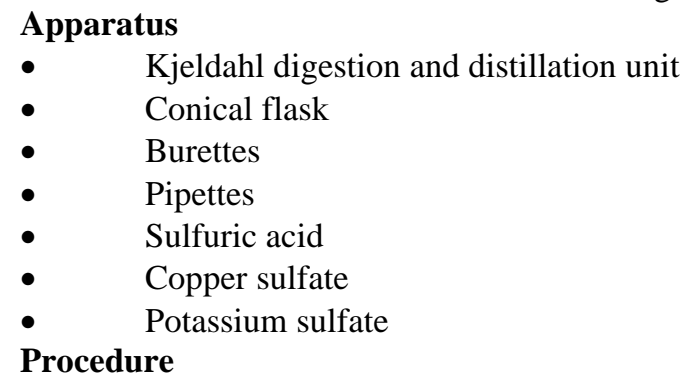

$5 \mathrm{gm}$. of oven dried, sieved soil sample was taken in a $500 \mathrm{ml} \mathrm{Kjeldahl} \mathrm{flask} \mathrm{and} \mathrm{then} 50 \mathrm{ml}$ of distilled water was added in it. $5 \mathrm{gm}$. of digestion catalyst mixture was added in the flask was kept for heating at $40-50^{\circ} \mathrm{C}$ for $20-30$ minutes on heating mantle and ten the temperature was increased to $100^{\circ} \mathrm{C}$ and the sample was digested for about 90 minutes. After that the digest was cooled and then $100 \mathrm{ml}$ distilled water was added in it. The supernatant was transferred to the distillation flask leaving as much soil behind. The soil residue was washed 3-4 times with distilled water and then transferred to the kjeldhal distillation flask. $100 \mathrm{ml}$ of $40 \% \mathrm{NaOH}$ was added in kjeldhal assembly along with zing granule and few glass beads. $25 \mathrm{ml}$ of boric acid indicator was taken in a $250 \mathrm{ml}$ conical flask and that was placed below the condenser distillation assembly in such a way that the lower end of the condenser was dipped in the solution. The distillation flask was heated on the heating mantle and around $175 \mathrm{ml}$ of distillate collected in the flask. Pink solution started turning green, the distillation flask was removed and then it was titrated with 0.01 N HCL and the end point was the original color. Then by using the formula the nitrogen content of each soil sample was determined.

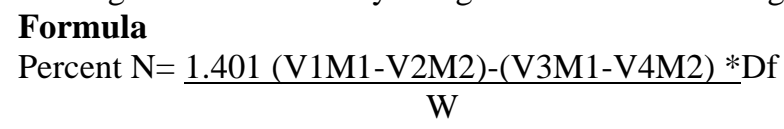

Where,

$\mathrm{V} 1=\mathrm{ml}$ of standard acid taken in receiving flask for samples

$\mathrm{V} 2=\mathrm{ml}$ of standard $\mathrm{NaOH}$ used in titration

$\mathrm{V} 3=\mathrm{ml}$ of standard acid taken to receiving flask for blank

$\mathrm{V} 4=\mathrm{ml}$ of standard $\mathrm{NaOH}$ used in titrating blank

M1= molarity of standard acid

$\mathrm{M} 2=$ molarity of standard $\mathrm{NaOH}$

$\mathrm{W}=$ weight of sample

\section{Principle:}

The extract of soil in ammonium acetate is atomized in the flame where the atoms of the element excited, emitting radiations emitted by sodium atoms is passed through the filter which falls on photocell emitting electrons, i.e. electric current which is measured in galvanometer of flame photometer. The electric current generated is proportional to the concentration of sodium to extract.

Apparatus

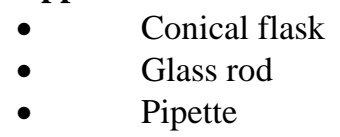

\section{Procedure}

A working of $100 \mathrm{ppm}$ was prepared from $1000 \mathrm{ppm}$ stock solution of $\mathrm{NaCl}$ by pipetting out $10 \mathrm{ml}$ from stock solution and then diluting it with distilled water up to $100 \mathrm{ml}$. from working solution different concentration ranges were prepared by pipetting out appropriate amount and diluting with distilled water up to the mark in volumetric flask. For unknown, 5 gm. oven dried, sieved soil sample was taken in $100 \mathrm{ml}$ beaker and $50 \mathrm{ml}$ ammonium acetate was added in it. The solution was mixed properly for 15-20 minutes and then filtered to get clear solution. The flame photometer was adjusted to $100 \%$ by using higher concentration solution that is $10 \mathrm{ppm}$ solution and then the readings for other concentration solution was taken along with the soil sample. The filter in flame photometer was selected accordingly. A standard graph of concentration versus absorbance was plotted to get the concentration of unknown (soil sample) and then by using the formula the sodium content for each soil sample was determined. 


\section{International Advanced Research Journal in Science, Engineering and Technology}

Vol. 8, Issue 9, September 2021

DOI: $10.17148 /$ IARJSET.2021.8930

\section{Formula}

$\mathrm{SAR}=\left[\mathrm{Na}^{+}\right] / \sqrt{1} / 2[\mathrm{Ca}+\mathrm{Mg}]$

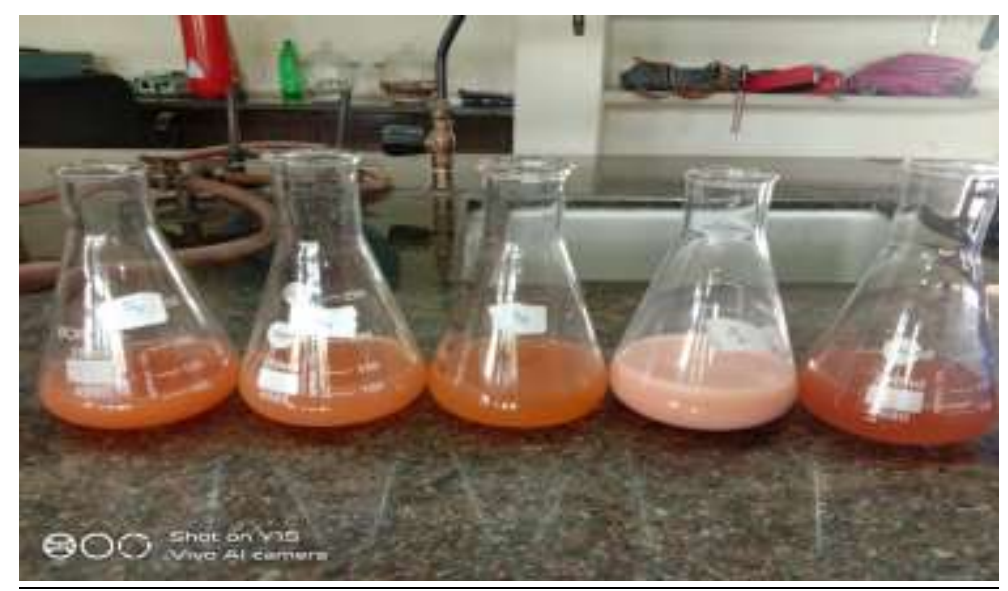

\section{Principle}

AVAILABLE POTASSIUM

The extract of soil in ammonium acetate is atomized in the flame where the atoms of the elements are excited, when the electron come back to the ground state they emits the radiations of characteristic wavelength. Potassium atoms emitted the radiation emitted and passed through the filter which falls on photocell that emits the electrons, i.e. electric current which is measured in galvanometer of flame photometer. The electric current generated is proportional to the concentration of potassium into the extract.

\section{Apparatus}

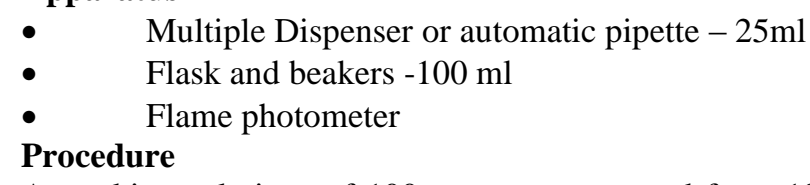

\section{Procedure}

A working solutions of 100 ppm was prepared from 1000 ppm stock solution KCL by taking out $10 \mathrm{ml}$ from stock solution and diluting it up to $100 \mathrm{ml}$ using distilled water. From the working solution concentration ranges were prepared by out appropriate amount and diluting it with distilled water. The concentration ranges were 2, 4, 6, 8 and 10 ppm. For soil sample, $5 \mathrm{gm}$ of dried, sieved soil sample was taken in a $100 \mathrm{ml}$ beaker and $50 \mathrm{ml}$ of ammonium acetate was added in it. The solution was mixed properly for 15-20 minutes, and then filtered to get clear solution. The flame photometer was adjusted to $100 \%$ by using higher concentration solution that is $10 \mathrm{ppm}$ solution and then the reading were taken for the other concentration and the soil sample. For the determination of potassium the respective filter is selected in flame photometer. After taking all the readings the concentration of unknown (soil sample) was determined by plotting a standard graph of concentration versus absorbance and the potassium content was determined using the formula.

\section{Formula}

$$
\mathrm{K}=\mathrm{A} * \frac{25}{5} * \frac{2000000}{1000000}=10 \mathrm{~A}
$$

\section{Principle}

\section{AVAILABLE PHOSPHOROUS}

In the filtered extract phosphorous estimated calorimetrically by adding ammonium and thereafter reducing the so formed molybdenum phosphate complex in acidic condition. The method is primarily based on the fact that acidic molybate solution reacts with orthophosphate ions present in the soil, which leads to formation of phosphate molybate complex that can be reduced by stannous chloride to form blue color molybdenum. The intensity of blue color determines the concentration of $\mathrm{P}_{2} \mathrm{O}_{5}$ in the solution.

\section{Apparatus}

- Flask

- Pipette

- Burette

- Glass rod 


\title{
International Advanced Research Journal in Science, Engineering and Technology
}

\author{
Vol. 8, Issue 9, September 2021
}

DOI: $10.17148 /$ IARJSET.2021.8930

\section{Procedure}

A working solution of 100 ppm was prepared from 1000 ppm stock solution. Concentration ranges were prepared from this working solution, by pipetting out proper amount of working in $50 \mathrm{ml}$ volumetric flask. The concentration ranges were $0.4,0.8,1.2,1.6 \mathrm{ppm}$. Then in each volumetric flask $2 \mathrm{ml}$ stannous chloride and $2 \mathrm{ml}$ ammonium molybate was added and then it was diluted up to mark with distilled water. For unknown, that is soil sample, 2.5 gm. of oven dried, sieved soil sample was taken in a $100 \mathrm{ml}$ beaker in that $50 \mathrm{ml}$ sodium bicarbonate solution was added. The sample was stirred continuously for 25-30 minutes and it was then filtered. $5 \mathrm{ml}$ from the filtered was pipette out in a $50 \mathrm{ml}$ volumetric flask in that $2 \mathrm{ml}$ of stannous chloride and ammonium molybate was added each. And then it was diluted with distilled water up to mark. Keep this for 10 minutes for color development. The absorbance of the concentration ranges and sample were taken at 660 nanometer using colorimeter. By plotting a graph of concentration versus absorbance the concentration of unknown was determined and then by applying formula phosphorous content of soil sample was determined.

\section{Principle}

\section{ENUMERATION OF BACTERIA}

From the different sample, a number of diluted suspensions are prepared firstly and then added to nutrient solutions contained in petridishes. These are incubated at room temperature for 24 hours. The number of colonies formed are counted in those dishes where the degree of dilution is suitable.

\section{Apparatus \\ - Petridish \\ - Pipettes \\ - Wire loop \\ Procedure}

$1 \mathrm{gm}$. of soil was mixed in the $10 \mathrm{ml}$ distilled water. Then took the loop full suspension and striking is done by the four quadrant method. After the completed sticking plate kept for incubation at room temperature for 24 hours. After 24 hours the no. of colonies were counted and by using the formula average number of bacteria was calculated.

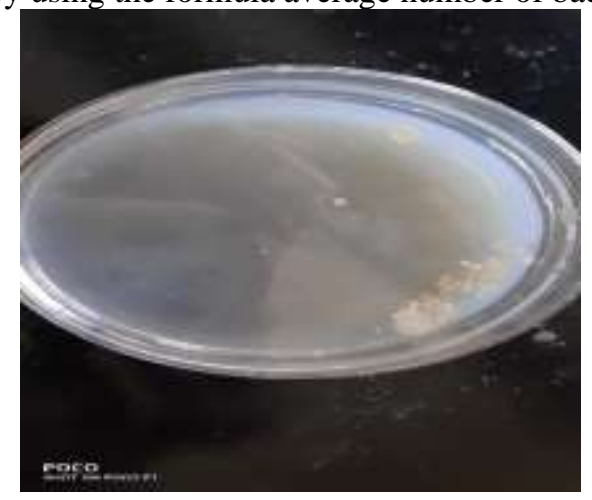

\section{pH meter}

\section{INSTRUMENTS USED}

$\mathrm{pH}$ meter, electric device used to measure hydrogen- ion activity (acidity and alkalinity) in solution. A pH mainly contains voltmeter which is attached to a $\mathrm{pH}$ respective electrode and a reference unvarying electrode. The $\mathrm{pH}$-responsive electrode is usually a glass electrode and the reference is usually mercury- mercuric chloride (calomel) electrode, although a silver-silver chloride electrode is sometime used. When the two electrode are immersed in a solution they act as a battery. The glass electrode develops an electric potential (charge) that is directly related to the hydrogen-ion activity in the solution and the voltmeter measures the potential difference between the glass and reference electrode.

\section{Conductivity meter}

Conductivity meter is an instrument commonly used for determination of conductivity of a solution. The meter is equipped with probe, usually handheld for field or on-site measurement. After the probe is placed in liquid it's measured, then the meter applies voltage between two electrodes inside present in the probe. Electrical resistance from the solution which cause drop in voltage, and is read by the meter. The meter converts this reading to milli or micromhos. This value indicates the total dissolved solids. Total dissolved solids are amount of solids that can pass through a glass-fiber filter.

\section{Autoclave}

Autoclave helps normally helps to destroy the pathogenic culture and work as disinfectant. They work with a combination of steam, time and pressure. Autoclaving is used to sterilize culture media, instruments, dressing, intravenous equipment, syringes and numerous other items that can with lands high temperature and pressure. The laboratory technician uses it 


\title{
International Advanced Research Journal in Science, Engineering and Technology
}

\author{
Vol. 8, Issue 9, September 2021
}

\section{DOI: 10.17148/IARJSET.2021.8930}

to sterilize bacteriological media and destroy pathogenic cultures. Water reaches its boiling point when its vapors pressure equals to that of surrounding atmospheric pressure and this is mainly principle of autoclave. When pressure is inside the closed vessel increases, the temperature at which water boils also increases. Steam condensed to water and gives up to latent heat to surface when it comes in to contact with the cooler surface. The water of the condensation is ensures moisture conditions for killing of the exposed micro-organism. Bacteria are intrinsically more susceptible to most heat as bacterial proteins coagulate rapidly and condensed water ensures moist conditions for killing the microbes present.

\section{Hot air oven}

Hot air oven generally used for dry heat to sterilize purpose. It is double walled chambers made up with steel. The degree of hot air oven is start from $50^{\circ} \mathrm{C}$ to $300^{\circ} \mathrm{C}$. Thermostat control inside temperature. Hot air oven generally made digitally controlled the temperature. The double walled insulation keeps the heat in and conserve the energy, inner layer is poor conductor and outer layer is made up by metallic. The working of the hot air oven is normally based on the hot air inside the chambers of oven by the forced circulation. It is universal scientific fact that in any chambers hot air rises above, so by utilizing this principle when the hot air reaches the hot air reaches the top of chambers and hence optimum amount of heat is gradually inside the hot air oven. After the heating content is completed after the 2 hours at $160^{\circ} \mathrm{C}$ the equipment are allow to remain there. After the complete cooling of hot air oven, the temperature come down to $40^{\circ} \mathrm{C}$, then removed the equipment from the oven.

\section{Colorimeter}

It is scientific technique that is to determine the concentration of colored compound present in solution. A colorimeter is a light sensitive device normally used for measuring the transmittance and absorbance of light passing through a liquid sample. In the colorimeter, a beam of light with a specific wavelength is passed through the solution via a series of lenses, which navigated the colored light to the measuring the difference between the amount of light at its origin and that after passing the solution. To determine the concentration of unknown sample, several sample solution of known concentration are first prepared and tested. The concentration are then plotted on a graph against absorbance, thereby generating a calibration curve. The results of unknown sample are compared to that of the known sample on the curve to measure the concentration.

\section{Flame photometer}

Flame photometer is an instruments generally used to determine the concentration of alkali and alkaline earth metals. These instrument are fairly simple, consisting of four basic components; a flame or burner, a nebulizer and mixing chamber, color filters and a photo detector. The compounds of the alkali and alkaline earth metals dissociate into atoms when introduced into the flame. Some of these atoms further get excited to even higher levels. But these atom are not stable at higher levels. Hence, these atoms emits radiations when returning back to the ground state. These radiations generally lie in the visible region of the spectrum. Each of the alkali and alkaline earth metal has a specific wavelength.

\section{Magnetic stirrer}

Magnetic stirrer is a laboratory technique which cause formation of stirrer helps in mixing of liquid. The rotating field is created due to rotating magnet field to cause a stir bar immersed in a liquid to spin very quickly and thus stirring the liquid. A stir bar is the magnetic bar which is placed within the liquid that provides the stirring action. The stir bar's motion is driven by another rotating magnet or assembly of electromagnets in the stirrer device, beneath the vessel containing the liquid. These is heating device in liquid. It is used in many biological laboratories, including microbiological laboratory also.

\section{Spectrophotometer}

Spectrophotometer is a much more refined version of a colorimeter. In a colorimeter, filters are used which allow a broad range of wavelengths to pass through, whereas in the spectrometer a prism (or) grating is used to split the incident beam into different wavelength. By suitable mechanism, waves of specific wavelength can be manipulated to fall on the test solution. Spectrophotometer helps to measure absorption maxima of compound that the wavelength at which light is absorbed.

\section{RESULT AND DISCUSSION}

The results of analysis are discussed with the possible reasons behind it. It also includes the recommendation. 1) $\mathbf{p H}$

The $\mathrm{pH}$ of soil sample ranges from 8. The correct balance is when the soil $\mathrm{pH}$ is between 5.5 and 7.5. The higher $\mathrm{pH}$ of Gujarat region of coastal area was 8.67. The reason for highly $\mathrm{pH}$ of coastal area could be due to discharged of calcium carbonate. Soil may be alkaline due to the over-liming acidic soil. Also one more thing is alkaline irrigation water may cause soil.

Soil $\mathrm{pH}$ is an indication of the acidity or alkalinity of soil and is measured in $\mathrm{pH}$ unit. The $\mathrm{pH}$ scale varry from $0-14$ with pH 7 as the neutral point. As the amount of ions in the soil increases, the soil pH decreases thus becoming more acidic. From $\mathrm{pH} 7$ to 0 the soil is increasingly more acidic and from $\mathrm{pH} 7$ to 14 the soil increasingly more alkaline condition. 


\title{
International Advanced Research Journal in Science, Engineering and Technology
}

\author{
Vol. 8, Issue 9, September 2021
}

DOI: $10.17148 /$ IARJSET.2021.8930

\section{2) Conductivity}

The soil of the all soil sample was found to be medium to high. The highest conductivity among all the sample was found in coastal area of Gujarat region is $0.263 \mu$ to maximum is found to be $2.59 \mu$

Factors influencing the electrical conductivity includes the amount and type of soluble salts, porosity, soil texture, and soil moisture and soil temperature. High level of precipitation can flush soluble salts out of the soil and reduce electrical conductivity. Electrical conductivity can get attached by inadequate irrigation practice which can wash away salts out of soil and beyond rooting depth.

Effective irrigation practices, which wash soluble salts out of soil and beyond the rooting depth, can decrease electrical conductivity. Adding organic matter such as manure and compost, increase electrical conductivity by adding cations and anions and improving the water holding capacity also.

\section{3) Water holding capacity}

The maximum water holding among all the soil sample was found to be $40.93 \%$. The reason for the highest or lowest water holding capacity could be kind of soil or texture of soil present in respective site. Different soil particle have different water holding capacity. The coastal area could be having for sandy soil and residential area having more clay particle in the soil which has the maximum capacity to hold the water. As it is rich in organic matter.

Soil organic matter is another factor that can help increase water holding capacity. If the farm increases the percentage of soil organic matter, the soil water holding capacity will increases.

\section{4) Organic matter}

The maximum organic content of given soil was found to be $0.66 \%$.The organic matter content of almost all samples was found to be low to medium. Less content of organic matter indicates that the soil lacks micro flora and fauna which ultimately results in organic matter. The surrounding atmosphere could affect it.

There are proven method to reduce losses of organic matter from given field. One of these is conservation tillage that means reducing soil disturbance, which consequently slows decomposition rate. Erosion control is another method for reducing the amount of soil organic matter lost from the soil. Organic matter can be increased by increasing inputs of organic material or decreasing losses.

Organic matter has a vital role in soil. It supplies plant nutrient, improve the soil structure, improves the water infiltration and retention. It contributes positively to higher crop yields. Soil with organic matter level about $3.4 \%$ is not be considerable to be vulnerable.

\section{5) Chloride content}

The chloride content was found to low i.e., between 0 to $1 \mathrm{mg} / \mathrm{liter}$. The maximum chloride was found to be $1.552 \mathrm{mg} / \mathrm{L}$. High levels of chloride in the soil solution will result in chloride toxicity in the plant elevated chloride levels. When allowed to exist, may directly result in plant toxicity or reduce the quality of harvested part of the plant.

Excess chloride due to irrigation water or excess soil salts (sodium chloride). Chlorine $(\mathrm{Cl})$ convert to chloride $\left(\mathrm{Cl}^{-}\right)$in the soil and is absorbed by plants in this form. Chloride toxicity is most common in irrigated, dry region, seacoast areas, and near roads frequently treated with salt in wintertime. Gypsum is used for reducing the chloride level. Incorporate into the soil at a rate of $58 \mathrm{lbs}$. per 1000 square feet, in loam soils. Less gypsum is needed in sandy soils, more in heavy clay soils. Water thoroughly to leach toxic of chlorine from the soil.

\section{6) Available phosphorous}

The available phosphorous content of all sample was found to be lower than the desired limits. Among all the soil sample the higher phosphate found to be $0.66 \%$. The high level of phosphorous content be due to application of fertilizers or due to coastal area.

The best way to increase the phosphate content is to increase the organic and humus. Adding phosphorous material to the compost pile greatly increase the phosphorous content and availability.

It is difficult to remove phosphorous from the soil but excess level can be remediated by using low phosphorous (or phosphorous free) fertilizers until the levels drop. It also a good idea to cease using phosphorus accumulating plant as mulach.

\section{7) Available potassium}

As per the standards, almost all the soil sample showed low to medium potassium content. The maximum content of potassium was found to be $0.12 \%$. Abundance of organic matter, excessive application of fertilizers or weathering of minerals in soil for example feldspar and mica causes due to increase in potassium content.

The potassium content can be decreased by eliminating the use of wood ash, potassium fertilizers or other known high potassium sources. Adding gypsum with water will leach excess potassium out of the topsoil. Adding organic potassium source can help to increase the potassium content in soil if it contain low potassium.

\section{8) Sodium SAR}

The high sodium content was found to be $85.70 \mathrm{~kg} / \mathrm{ha}$. The high content of sodium in the agricultural soil could be due over application of fertilizers or the runoff from the upper region which carry all the ions along with it and gets deposited in the small area where the study area is located. 


\begin{tabular}{|c|c|c|c|c|c|}
\hline \begin{tabular}{|l} 
Sr.y No \\
$(5)$ \\
\end{tabular} & \multicolumn{5}{|c|}{ International Advanced Research Journal in Science, Engifles/hing and Technbregeria (cfu/ml) } \\
\hline 1 & Sample 1 & $\begin{array}{l}0.22 \text { Vol. } 8 \text {, Issue } \\
\text { DOl: } 10.17148\end{array}$ & $\begin{array}{l}9, \S .9 Q^{t e m b e r} 2021 \\
\text { |IARJSET.2021.893 }\end{array}$ & ${ }_{0}^{85.70}$ & 76 \\
\hline 2 & Sample 2 & - & - & 11.67 & 72 \\
\hline 3 & Sample 3 & 0.66 & 0.66 & 15.39 & 77 \\
\hline 4 & Sample 4 & - & - & 5.36 & 34 \\
\hline 5 & Sample 5 & - & - & 6.8 & 7 \\
\hline 6 & Sample 6 & 0.07 & 0.07 & 61.1 & 53 \\
\hline 7 & Sample 7 & 0.08 & 0.08 & 11.99 & 27 \\
\hline
\end{tabular}

The sodium content can be deceased by increasing the organic matter, leaching the excess sodium with gypsum and clean water or by increasing the soil microbiological activity by inoculating the soil with sodium-eating microbes. Sodium is an essential elements for plant growth, but is never found deficient in the soil. Excessive sodium is the most common problem. High levels of sodium makes the soil sodic causes plant and microbial problems and very high levels cause sterilization and plant damage or death.

\section{9) Available nitrogen}

The maximum nitrogen content found to be $21.56 \%$. Due to heavy rains there as always of significant nitrogen (N) loss due to leaching and denitrification particularly when the weather is warm. Heavy rains after nitrogen application can create considerable loss of soil nitrates and create a source of pollution. Nitrogen deficiencies basically occurs in soil which valve high content of organic matter which is not sufficiently decomposed. Product like sawdust, grass clipping make use of nitrogen from soil as they decompose and hence rob the soil of nitrogen leaching and leaving the soil.

\section{0) Enumeration and characteristic of bacteria}

The maximum activity of bacteria was found to be 77 colonies was found and characteristics of one colony is studied. The size of that colonies is $0.2 \mathrm{~mm}$, circular shape, orange in color, opacity of that colony was found to be opaque, margin is round and elevation of that colony was concave. The more microbial activity in the soil, the more good for soil condition.

The microorganism activity in soil depends on many factor like soil moisture content, temperature, texture and availability of nutrients.

Soil microorganism are vital and for the containing cycling of nutrients and for driving above ground ecosystems. Soil bacteria play very important andpivotal role in various biogeochemical cycles. Soil microorganism and influences above ground ecosystem by contributing to plant nutrition, plant health, soil structure and soil fertility. However activity and species composition of microbes are generally influenced by many factors including physic-chemical properties of soil, temperature and vegetation. The dynamic of soil microorganism have important implication for the response of subsurface soil ecosystem to perturbations.

\section{Observation table}

\begin{tabular}{|l|l|l|l|l|l|l|l|}
\hline Sr. no & Sample & $\mathbf{p H}$ & Conductivity & WHC \% & $\begin{array}{l}\text { Chloride } \\
\mathbf{M g} / \mathbf{l}\end{array}$ & $\begin{array}{l}\text { Organic } \\
\text { matter\% }\end{array}$ & N \% \\
\hline 1 & Sample1 & 8.26 & 2.53 & 40.93 & 1.552 & 0.64 & 13.44 \\
\hline 2 & Sample 2 & 8.52 & 1.053 & 16.7 & 0.0425 & - & - \\
\hline 3 & Sample 3 & 8.64 & 0.356 & 31.2 & 0.16307 & 0.66 & 22.4 \\
\hline 4 & Sample 4 & 8.33 & 0.263 & 35.1 & 0.11328 & - & - \\
\hline 5 & Sample 5 & 8.26 & 2.59 & 31.6 & 0.04963 & - & - \\
\hline 6 & Sample 6 & 8.67 & 0.307 & 18.2 & 0.10635 & 0.66 & 17.36 \\
\hline 7 & Sample 7 & 8.65 & 1.53 & 23.4 & 0.0098 & 0.7 & 21.56 \\
\hline
\end{tabular}

Desirable limit of soil parameter

\begin{tabular}{|l|l|l|l|l|}
\hline Sr. No. & Parameters & Unit & Level & Soil condition \\
\hline 1. & $\mathrm{pH}$ & Unit less & $0-6.9$ & Acidic \\
& & & 7 & Neutral \\
& & & $7.1-14$ & Alkaline \\
\hline 2. & Conductivity & $\mu$ mho/cm & Less than 0.75 & Low \\
\hline
\end{tabular}


International Advanced Research Journal in Science, Engineering and Technology

Vol. 8, Issue 9, September 2021

DOI: $10.17148 /$ IARJSET.2021.8930

\begin{tabular}{|c|c|c|c|c|}
\hline & & & $\begin{array}{l}0.75-1.5 \\
1.5-3 \\
\text { More than } 3 \\
\end{array}$ & $\begin{array}{l}\text { Medium } \\
\text { High } \\
\text { Very high }\end{array}$ \\
\hline 3. & Organic matter & $\%$ & $\begin{array}{l}0.1-1.5 \\
1.6-3.0 \\
3.1-4.5 \\
4.6-6.0 \\
\text { More than } 6.0\end{array}$ & $\begin{array}{l}\text { Very low } \\
\text { Low } \\
\text { Medium } \\
\text { High } \\
\text { Very high }\end{array}$ \\
\hline 4. & $\begin{array}{l}\text { Available } \\
\text { phosphorous }\end{array}$ & $\mathrm{Kg} / \mathrm{ha}$ & $\begin{array}{l}\text { Less than } 11 \\
11-22 \\
\text { More than } 22\end{array}$ & $\begin{array}{l}\text { Low } \\
\text { Medium } \\
\text { High }\end{array}$ \\
\hline 5. & $\begin{array}{l}\text { Available } \\
\text { potassium }\end{array}$ & $\mathrm{Kg} / \mathrm{ha}$ & $\begin{array}{l}\text { Less than } 110 \\
110-280 \\
\text { More than } 280\end{array}$ & $\begin{array}{l}\text { Low } \\
\text { Medium } \\
\text { High }\end{array}$ \\
\hline 6. & SAR & $\mathrm{Kg} / \mathrm{ha}$ & $\begin{array}{l}1-40 \\
41-80 \\
81-120 \\
121-160 \\
\text { More than } 160 \\
\end{array}$ & $\begin{array}{l}\text { Very low } \\
\text { Low } \\
\text { Medium } \\
\text { High } \\
\text { Very high }\end{array}$ \\
\hline 7. & Chloride content & $\mathrm{Mg} / \mathrm{liter}$ & $\begin{array}{l}0.5-9.9 \\
10-20 \\
\text { More than } 20\end{array}$ & $\begin{array}{l}\text { Low } \\
\text { Medium } \\
\text { High }\end{array}$ \\
\hline 8. & Available nitrogen & $\%$ & $0.02-2$ & Average \\
\hline
\end{tabular}

\section{CONCLUSION AND RECOMMEDATION}

Introduction

Introduction of soil, its component, importance in the environment and the current status of soil that is, degradation of soil quality due to various man- made as well as natural reasons. It also idea about the physiochemical and microbiological parameters of soil, its importance in maintaining the soil quality. It also include the main aim and the objectives of this project and the study area.

Review literature

It contain all the review of literature that is done while doing this project. Many research papers, articles, method has been studied for reference and that is included in this part with little information about the project, research etc. and the conclusion drawn from it.

Materials and methodology

It include material and methodology used for the project. Detailed information right from the sampling to the storage and analysis is given in this part. Procedure followed to do the analysis along with principle behind it. Various instrument have been used during this project.

Results and discussion

This contain the main observation table of the project. All parameters with respect to all location are mention in this part along with the units. This also includes the standard value described by different authorities for different parameters to maintain quality and ultimately to compare the result with standard to draw the conclusion. As the soil directly or maintain the nutrient balance in ecosystem, it is very important to maintain the health of the soil which can be done according to the result of soil analysis. Hence it is important to analyze the soil condition after certain time.

As result of soil analysis of Gujarat region near to coastal area indicate that the soil quality affected due to either anthropogenic activities or some natural activities as it show imbalance in the nutrient content in some area. The all soil are alkaline found. The study also revels the status of soil along the near coastal soil, where the agricultural activities carried out, it's clearly show that in three region there no content of nitrogen, phosphorous and potassium. And other four region having the abundance growth of essential nutrient present in the soil for proper growth but some time additionally put the fertilizers in the soil that contains these nutrients in order to fasten the crop growth but excessive application lead to accumulation in soil and ultimately in plant, and anything in excess is toxic. So care has to be taken while growing the plant and regular soil checking has to be done in order to determine the quality of soil.

As the sampling was done during this project and only representative places were selected for the analysis of soil from respected area which can be considered as a restricted data and hence the soil condition of each area is analyzed. Continue sampling and analysis from each location of district has to be done. Also some recommendation are given which can be applied to maintain the soil quality especially where can be applied to maintain the soil quality especially where the agricultural activities are carried out. 


\title{
International Advanced Research Journal in Science, Engineering and Technology
}

\author{
Vol. 8, Issue 9, September 2021
}

DOI: 10.17148/IARJSET.2021.8930

\section{REFERENCES}

[1] Kirti Mohan Sharma and Hardev Singh Chaudhary (2017) Physico Chemical Analysis of soil Ladpura Tehsil of Kota District. International journal of pure and applied Bioscience.

[2] Miss Yogita Kulkarni, Dr. Krishna K. Warhade, Dr. Susheel Kumar Bahekar (2014) Primary Nutrients Determination in the soil using UV spectroscopy, international journal of emerging engineering research and technology.

[3] Sarah Kizza, Otlogetwe Totolo, Jeremy Perkins and Olusegun Areola (2010), analysis of persistence soil nutrient status in abandoned cattle kraals in a semi-arid area in Botswana.

[4] B.V. RamaKrishana, Dr. B.Satyanarayana (2016), Agriculture Soil Test Report Data Mining for cultivation Advisory, International Journal of computer Application (2250-1797).

[5] Zeeshan akram, Sajid Hussain, Mudassir Mansoor, Muhamaad Afzal, adil waqar Imran shabbier (2014), soil fertility and salinity status of Muzaffagarh district, Punjab, Pakistan, universal journal of agricultural Research 2(7) 242-249, 2014.

[6] Abubaker Haroun Mohamed Adam, Ismail Mohamed fangama abdalla, Mohamed Abdelkrein, Gammareldain, A. Ibrahim (2015), Analysis of Soil NPK, $\mathrm{pH}$ and Electrical Conductivity At Adhan Area -Renk, upper Nile State, INTERNATIONAL JOURNAL OF SCIENTIFIC \& TECHNOLOGY RESEARCH VOLUME 4, ISSUE 12, DECEMBER 2015.

[7] K. Perumal, S. Ananthi, J. Arunkumar (2016), Innovative and simplest alternative analytical technology (AAT) for testing soil nutrients, journal of soil science research.

[8] K. Mainmegalai and S Sukanya, (2014) Assessment of physico-chemical parameters of soil of Muthannan Kulum Wetland, Coimbatore, Tamil Nadu, India, and international journal applied science and biotechnology.

[9] Teruo Yamamto, soil moisture constant and physical properties of selected soils in Hawaii.

[10] Katy Buthchee, Daryl B. Arnall, Apurba Sutradhar, Chad Penn (2012), determining Critical Soil pH for Grain Sorghum Production, International journal of Agronomy.

[11] Ramesh Babu Palepu, Rajesh Reddy Muley (2017) An Analysis of agricultural Soil by using Data Mining Techniques.

[12] Komal Abhang, Surabhi Chaugale, Pranali Chavan, Shradha Ganjave(2018), soil Analysis and crop fertility prediction, international Research paper of engineering and technology.

[13] Kiran G. Chaudhari (2013), studies of physicochemical parameters of soil samples.

[14] SS Kekane, RP chavan, DN Shinde, CL Patil, SS Sagar(2015), A review on physico-chemical properties of soil, international journal of chemical studies.

[15] Shivkumar D, Srikantaswamy S (2012), Study of physicochemical characteristics of industrial zone soil- A case study of Mysore city, Karnataka, India, International Journal of Environmental Sciences.

[16] Mohd Salim, Pramod Kumar, M.K. Gupta and Saurabh Kumar (2015), Seasonal Variation in some chemical characteristics of the soil under different land used of Jhilmil Jheel wetland, Haridwar -Uttarakhand, India, International Journal of Scientific and Research Publication.

[17] Valleric Vranova, Theodore Danso Marfo, Klement rejesk (2015), Soil Scientific Research Methods Used in Archaeology- Promising Soil Biochemistry: A Mini Review.

[18] J.L. Walworth, soil Sampling and analysis.

[19] Swanti. A. Jain, M.S.Jagtap, K.P Patel (2014), physicochemical characterization of farmland soil used in some village of lunawada Taluka, Dist: Mahisagar (Gujarat), India. International journal of scientific and research publications.

[20] Wagh G.S. chavan, D.M. and Sayyed M.R.G. Physicochemical Analysis of soil from Eastern part of pune city, Universal Journal of Environmental Research and Technology.

[21] Research paper- Important of soil quality and soil agriculture indicators (2014), Academia Journal of Agricultural Research.

[22] Dr. Syed Ummul Khair Asema, Dr. Shaikh Taranum Tanveer, Dr. Sayyed Sultan (2015), Analysis of Soil Sample for its Physicochemical Parameters from Aurangabad City, International Journal of Innovative research \& Development.

[23] Sonikajha and Suneetha V, Nutrients analysis of soil samples from various places, Journal of Chemical and Pharmaceutical Research, 2015.

[24] Dr. Christine Watson, Elizabeth Stockdale and Lois Philipp's, Soil Analysis and Management.

[25] Jay Gholap, Anurag Ingole, Jayesh Gohil, Sahilesh Gargade, Vahida Attar (2012), Soil Data Analysis Using Classification Techniques and Soil Attributes Prediction, IJCSI International Journal of Molecular Sciences.

[26] Iaon Suciu, Constantine Cosma, Mihai Todica, Sorana D. Bolboaca and Lorentz Jantaschi (2008), Analysis of Soil Heavy Metal Pollution and Pattern in Central Translyvania, International Journal of Molecular Sciences.

[27] F. Najeral, Y. Tapia, C.Baginsky, V. Figueroa, R. Cabeza and O.Salazar (2015), Evaluation of soil fertility and fertilization practices for irrigated maize under Mediterranean conditions in central Chile, Journal of Soil Science and Plant nutrition.

[28] DR. Donald S. Loch, soil nutrient testing: How to get meaningful results.

[29] Minh Van Dang, (2007), Quantitative and qualitative soil quality assessment of tea enterprises in Northern Vietnam. African Journal of Agricultural Research.

[30] P.S. Kulkure, Importance of soil testing, collection of soil sample, its processing and Handling in laboratory.

[31] Shubhanath Behera, (2012), Physicochemical and microbial analysis of water and soil samples in proposed coal mine area at latehar.

[32] D.A. Horneck, D.M. Sullivan, J.S. Owen and J.M. Hart, Soil Test Interpretation Guide.

[33] Jacqueline Gibson, Diana Bateman, Phillip Ten Eyck, Paul Ruben (2013) the effect of soil conditions on plant health at the University of Central Florida.

[34] http.//agritech. Tnau.as.in/agriculture/agri soil soilratingchart.html

[35] Interpreting A Soil test Report- Agvise Laboratories Book referred: S.K. Maiti (2014) Handbook of methods in Environmental studies.

[36] Himanshu Sekhar Behera; Bijoy kumar pany. "Soil properties of medium land rice (Oryza sativa L.) in inorganic nitrogenous fertilizers on fym combination in yield". International Research Journal on Advanced Science Hub, 3, Special Issue ICIES-2021 4S, 2021, 46-49. doi: 10.47392/irjash.2021.109

[37] Toomula Srilatha; Jyothi Sree C.. "Survey on Plant Diseases Prediction using Machine learning for better Crop Yield". International Research Journal on Advanced Science Hub, 3, Special Issue 6S, 2021, 1-5. 